\title{
POSTMODERNISM AND PERFORMANCE
}




\section{Postmodernism and Performance}

NICK KAYE

Macmillan Education 
ISBN 978-0-333-51918-9

ISBN 978-1-349-23334-2 (eBook)

DOI 10.1007/978-1-349-23334-2

(C) Nick Kaye 1994

Softcover reprint of the hardcover 1st edition 1994 978-0-333-51917-2

All rights reserved. For information, write:

Scholarly and Reference Division,

St. Martin's Press, Inc., 175 Fifth Avenue,

New York, N.Y. 10010

First published in the United States of America in 1994

ISBN 978-0-312-12023-8 (cloth)

ISBN 978-0-312-12024-5 (paper)

Library of Congress Cataloging-in-Publication Data

Kaye, Nick.

Postmodernism and performance / Nick Kaye.

p. $\mathrm{cm}$.

Includes bibliographical references and index.

ISBN 978-0-312-12023-8 (cloth). — ISBN 978-0-312-12024-5 (pbk.)

1. Theater. 2. Performing arts. 3. Postmodernism. I. Title. PN2037.K35 1994

$792-\mathrm{dc} 20$

93-32470

CIP 


\section{Contents}

General Editor's Preface vi

Acknowledgements vii

Introduction: Limiting the Postmodern 1

1 From Postmodern Style to Performance 5

2 Theatricality and the Corruption of the Modernist Work 24

3 Looking Beyond Form: Foreman, Kirby, Wilson 46

4 Modern Dance and the Modernist Work 71

5 The Collapse of Hierarchies and a Postmodern Dance $\quad 90$

6 Telling Stories: Narrative Against Itself 118

Conclusion: Postmodernism and Performance 144

$\begin{array}{ll}\text { Notes } & 147\end{array}$

Select Bibliography 163

Index 173 


\section{General Editor's Preface}

In the past ten years, Theatre Studies has experienced remarkable international growth, students seeing in its marriage of the practical and the intellectual a creative and rewarding discipline. Some countries are now opening school and degree programmes in Theatre Studies for the first time; others are having to accommodate to the fact that a popular subject attracting large numbers of highly motivated students has to be given greater attention than hitherto. The professional theatre itself is changing, as graduates of degree and diploma programmes make their way through the 'fringe' into established theatre companies, film and television.

Two changes in attitudes have occurred as a result: first, that the relationship between teachers and practitioners has significantly improved, not least because many more people now have experience of both; secondly, that the widespread academic suspicion about theatre as a subject for study has at least been squarely faced, if not fully discredited, Yet there is still much to be done to translate the practical and educational achievements of the past decade into coherent theory, and this series is intended as a contribution to that task. Its contributors are chosen for their combination of professional and didactic skills, and are drawn from a wide range of countries, languages and styles in order to give some impression of the subject in its international perspective.

This series offers no single programme or ideology; yet all its authors have in common the sense of being in a period of transition and debate out of which the theory and practice of theatre cannot but emerge in a new form.

JULIAN HILTON 


\section{Acknowledgements}

In the course of completing this book, many people have been generous with their time and interest and I have received invaluable support from institutions and funding bodies. The University of Warwick granted me a period of study leave which allowed the project to be completed. An important part of my research would not have been possible without financial support from the British Academy, the University of Warwick and the Joint School of Theatre Studies of the University of Warwick, which allowed me to undertake a period of study in New York. Here I was greatly assisted by the staff of the Museum of Modern Art, the Performing Arts Research Center, the Dance Collection and the Jerome Robbins Archive of the Recorded Moving Image of the New York Public Library at Lincoln Center. I should also like to thank those artists and other individuals whose generosity with their time, and help with source material, has been much appreciated. In particular, I should like to thank Michael Kirby, Joan Jonas, Richard Foreman, Ping Chong, Elsa Jacobson of the Brooklyn Academy of Music, Richard Schechner, George Ashley, and Bruce Allardyce of the Ping Chong Company. Finally, I should like to express my gratitude to the late John Cage for an interview of special value to this book, but which was conducted before this project was conceived.

The author and publishers wish to thank Peters Edition Ltd, London, for permission to reproduce $4^{\prime} 33^{\prime \prime}$ and $0^{\prime} 00^{\prime \prime}\left(4^{\prime} 33^{\prime \prime}\right.$ No. 2) by John Cage.

Every effort has been made to trace all copyright holders, but if any have been inadvertently overlooked the publishers will be pleased to make the necessary arrangements at the first opportunity.

N. K. 
To Diane 